\title{
Poema: Lo que callé
}

\section{Poem: What I Shut}

\section{Susana Pérez de Correa}

Estudiante de Literatura

Universidad Autónoma de Bucaramanga

sperez81@unab.edu.co

Artículo recibido el 10 de marzo 2015

Artículo aprobado el 04 de mayo 2015

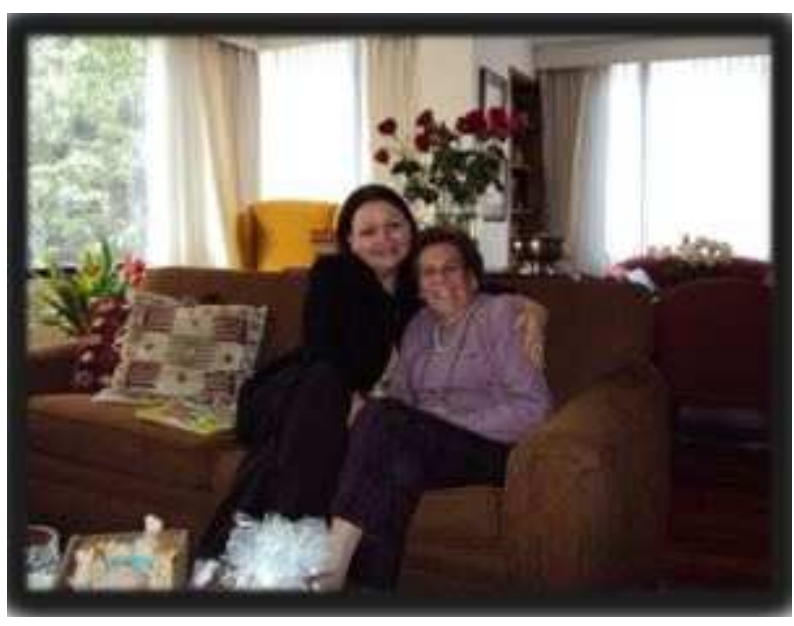

Fotografía de Yaneth Lizarazo. Directora de la revista con la poeta Susana Pérez. Registro personal.

\section{"Enhebrando los recuerdos}

de mi vida

y pensando en el tiempo

que me queda,

me preguntó que tengo

de locura

que sentada ante esta máquina 
tan fea, pueda escribir sentimientos

tan profundos

y decir las cosas

que jamás diría.

Son tantos los años que

han pasado

y tantos los poemas que

he leído

que no se sí lo que digo

lo he copiado

¡oh sí yo misma alguna vez

lo habré sentido!

Empezando con recuerdos del pasado,

las monjas, las lecturas, el tejido

las clases de costura y el dechado

la vida de los santos que leían.

El dechado de virtudes y el dechado de costura

fueron mi confusión toda la vida,

con el de costura más o menos

yo podía - algo cosía.

Pero el de las virtudes,

era lo más confuso y complejo

que existía.

La pureza siempre la confundí

con la pereza,

la castidad yo nunca la entendí

ni ahora!

Pero no examinaron mi dislexia

deja mucho que desear

se repetía,

yo no logré entender jamás 
aquella frase tan ambigua y loca

lo que sí muy temprano

comprendí es que

era mejor pensar

que abrir la boca.

Siempre que pregunté

metí la pata

entonces resolví

tratarlo de entender

yo sola.

Fue muy difícil resolver

tanto misterio

pero por fin descubrí la diferencia

que existe entre vivir

y la conciencia.

Mucho más crecidita,

yo creía

que el mundo entero se movía

con solo controlar esas pasiones

y escribía,

a veces a mami le mostraba

y se reía,

"haga algo útil, coja oficio

rómpase esos papeles, "me decía

"no vaya y se lo lean sus hermanas

y creyéndole tantas tonterías

se empiecen a volver paganas".

Hasta ahí se llegó mi

verso escrito

Yo jamás se lo mostré a ninguno

pero en las cuentas 
que saque al principio

he visto que si no le doy apuro

se me puede quedar en el oscuro.

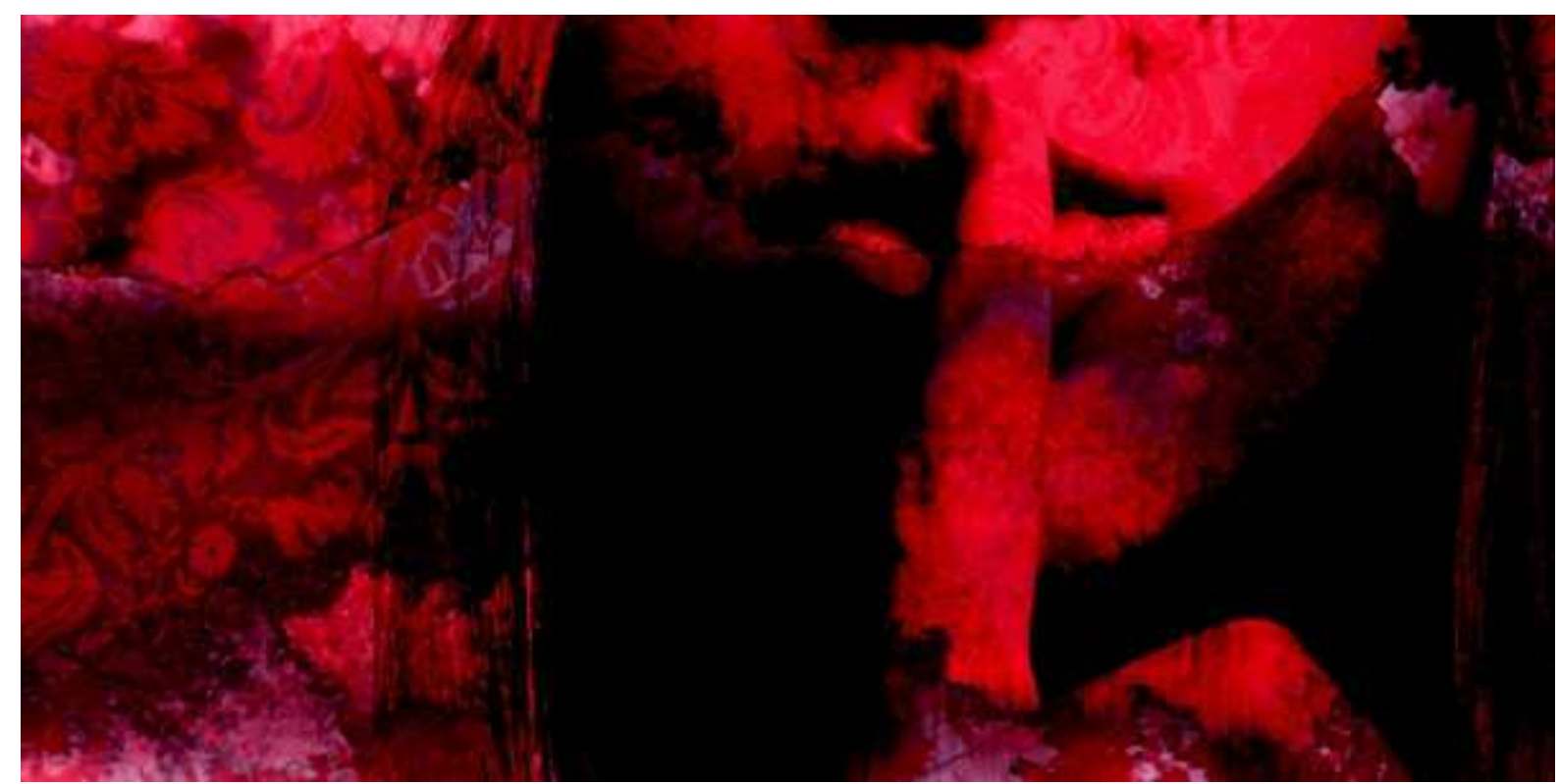

